\title{
Abstract \\ A critical examination of the knowledge contribution service user and carer involvement brings to social work education
}

\author{
Kieron Hatton
}

Service user/carer involvement in social work education is supported by the HCPC (Health Care Professions Council) and currently, by the Department of Health. It is generally seen as beneficial but the reasons why this may be the case are often under-theorised and seen as un-problematic. This article seeks to provide a theoretical justification for an approach which values involvement as central to educational practice.

It begins by looking at models of participation and how they can help us understand processes of involvement. It suggests that to move beyond tokenistic approaches we need to develop an approach which is based on equality and partnership. Drawing on European approaches to social pedagogy, particularly those utilising 'the Common Third', and debates around creativity and social power the article articulates an approach based on the co-production of curricula and assessment artefacts. This, the paper suggests, tests the students ability to empathise and communicate with people using services and utilises the latters' personal expertise to bring the curricula alive.

The article outlines a theory of creativity, inclusion and power which the author believes validates the approach developed and which provides a model for evaluating the real level of recognition given to the service user/carer voice within the educational process, particularly in social work education. It is suggested that such an approach is consistent with the social work professions' commitment to the promotion of social justice and social change (IFSW, 2014) 


\section{Introduction}

From somewhat limited beginnings service user/carer involvement has become central to the accreditation and validation of social work programmes (Hatton, 2015). The introduction of degree and Masters level qualifications in 2003 and the support of service user/carer involvement by grant monies from the Department of Health (admittedly at a relatively low level of $£ 7500$ per annum) has been maintained so far following the demise of the General Social Care Council and its replacement by the new HCPC regime in 2013. However, the extent and depth of service user/carer involvement varies widely across the country and in many, but not all, cases focuses on the involvement of service users/carers in the more traditional elements of the programme - admissions interviews, guest teaching, as an expert speaker. This paper suggest that if we are to make service user/carer involvement meaningful we need to develop a more holistic and complex way of understanding how service users/carers can contribute to social work education. This will involve seeing this involvement not as a way of legitimising our commitment to inclusion but seeing service users/carers as co-producers and partners in the educational experience. To achieve this the paper argues we need a more developed analysis of power, agency, imagination and creativity. The paper uses the phrase service users/carers for clarity although it fully recognises that a) service users/carers are not a homogenous grouping and b) that the very words are themselves contentious (McLaughlin, 2009). The author also recognises that service users/carers have multiple identities beyond their status as service users/carers. For example, looked after children, parents, carers themselves, advocates, stakeholders (particularly in Third Sector organisations) service deliverers etc and that many of these roles intersect (Goodley, 2011) and cause contradictions/conflicts. This is the content of a companion piece and will be dealt with in a separate article.

\section{The development of service user involvement}

Over the last ten to fifteen years, service users/carers have at last been recognised as having a significant role in the delivery, management and development of welfare services. This is reflected in the attention given to service user involvement in both the legislative and policy contexts. These debates cut across all service boundaries and raise questions about service user representation (Warren, 2007; Stepney and Popple, 2008; Payne, 2014), the efficacy of current initiatives (SCIE, 2004) and the usefulness of the service user perspective across a range of service user areas: young people (Hayden et al, 1999; Children's Rights Alliance and National Youth Council of Ireland, 2002); people in poverty (Bennett and Roberts, 2004; Beresford and Hoban, 2005); evaluating community outcomes (Jakes and Cassidy, n.d.); homeless people (FEANTSA, 2009); and with traditional 
service user groups such as people with mental distress, people with disabilities and older people.

The drivers behind these initiatives have often been service users themselves. The role of disability activists in creating the political climate to support anti-discriminatory legislation around disability is well known (Shakespeare, 2013), as was their role in ensuring that the Disability Discrimination Act 1995 was amended to give disabled people the right to enforcement action if their entitlements were not met. Equally, the voice of the service user can be seen in the Valuing People White Paper (Department of Health, 2001) and subsequent policy developments which grew out of that, including Valuing People Now (HM Government, 2009). The White Paper enshrined the concepts of rights, independence, choice, inclusion, and argued that

people with learning disabilities have little control over their lives... The Government's objective is to enable people with learning disabilities to have as much choice and control as possible over their lives and the services and support they receive.

(Department of Health, 2001, p4)

Recently the development of services incorporating personalisation and co-production have provided an important motor for this enhanced move toward empowering people in the adult social care sector. The seven core principles for self-care promoted by Skills for Care and Skills for Health in 2009 suggested that services should ensure that people are able to make informed choices, communicate their needs effectively, develop skills in selfcare, be supported to access other networks and 'support and enable risk management and risk taking to maximize independence and choice' (Department of Health, 2010, p44). This is supported further by Local Authority Circular/Department of Health which says that personalisation is about 'every person across the spectrum of need, having choice and control over the shape of his or her support, in the most appropriate setting' $(2008, \mathrm{p} 2)$.

Such an approach was further developed in the proposals around co-production which placed the emphasis on users and user-led organisations. Ramsden (2010) cites the Personal Communications Toolkit, which describes co-production as occurring when: 
[y]ou as an individual influence the support and services you receive, or when groups of people get together to influence the way that services are designed, commissioned and delivered.

(Ramsden, 2010; emphasis added)

The Social Care Institute for Excellence (2013) has produced a guide to co-production which, suggests that it is possible to identify some key features that are present. Coproduction they suggest:

- define(s) people who use services as assets with skills and breaks(s) down the barriers between people who use services and professionals

- build(s) on people's existing capabilities and include(s)reciprocity (where people get something back for having done something for others) and mutuality (people working together to achieve their shared interests)

- (enables people to) work with peer and personal support networks alongside professional networks while facilitating services by helping organizations to become part agents for change rather than just being service providers.

(SCIE, 2013, p7)

One of the organisations consulted on the development of the guide Think Local Act Personal are quoted as saying:

Co-production is not just a word, it's not just a concept, it is a meeting of minds coming together to find a shared solution. In practice, it involves people who use services coming together to find a shared solution. In practice it involves people who use services being consulted, included and working together from the start to the end of any project that affects them.

(Ramsden, 2010:7)

Three features of personalisation - design, commission and delivery - are critical to our ability to distinguish whether involvement has any meaning. Equally the key elements of co-production involve promoting people's strengths, reciprocity and mutuality, and the idea of people as change agents. All of these ideas resonate with the key debates with which we will need to engage if we are to take forward discussions around service user/ 
carer involvement. Ideas of co-production, in particular, link closely to the concerns within this paper about how we develop 'meaningful' ways of securing the involvement of service user/carers in the delivery of social work education.

\section{Service user/carer involvement in social work education}

There has been a developing literature around the involvement of service users/carers in higher education. Lathlean et al (2006) have looked at the challenges health care education faces involving service users and suggest that previous poor experience of participation by service user participants led to feelings of tokenism which, 'devalues user initiatives and reinforces 'institutional userism' which leads to exclusion and disempowerment' (2006:736). They suggest that there needs to be a commitment to service and organisational change to counteract these tendencies. Townend, Tew, Grant and Repper (2008) argue that the training of psychological therapists could be enhanced through, 'greater engagement from people who have experience of using psychological therapy services' (2008:75). They suggest that this could occur at a number of levels including interviewing for programmes, assessment, direct delivery commissioning and planning and by promoting alternative models of distress, risk and recovery. However they warn that such interventions are not always experienced positively and warn that, 'confrontation, lack of support and not being valued can lead to emotional distress' (p.71). It is with these issues in mind that we advocate in this paper supportive, co-produced and creative approaches to involvement.

Over ten years ago SCIE (2004b) suggested that service users should be involved at a strategic and management level with universities social work programmes. This may include involvement at programme management and partnership levels (although this is an area of collaboration and partnership which remains underdeveloped at present). It is more likely to focus on, selecting students; teaching and learning provision; placement learning opportunities - the opportunity to work with and within service user-controlled organisations assessment of students; quality assurance. SCIE noted the connection between values underpinning service user organisations and social work. They argued:

The service user movement emphasises the importance of models of participation that are based on human rights, equalities, inclusion and the social model of disability. Their approaches seek to empower people and counter oppressive and discriminatory practice. There is overlap between the values of service user-controlled organisations and those of social work and social care.

(SCIE, 2004b, p11) 
Beresford argued that to achieve such a level of involvement entails a focus on values treating service users with honesty, openness, respect, equality and of course commitment, and strategy, which will involve 'a fundamental culture change. We will all need to do things differently and changes in practice -supporting service user training, developing user-controlled organisations, addressing diversity, research, evaluation and payment' (SCIE, 2004b, pp13-14).

\section{Involvement across the curricula}

Wilson and Beresford (2000) have warned against a simplistic attempt to suggest that a commitment to anti-oppressive values of itself ensures that service users' views are heard and respected. Instead they argued that:

[s] uch a theory [of anti-oppressive practice] is by definition reliant upon user knowledge and ideas. Social work's adoption of a façade of 'anti-oppressive practice' which in reality appropriates and incorporates the knowledge and experiences of service users, whilst retaining the power to determine just what it is that counts as 'anti-oppressive' is for us the most oppressive aspect of its anti-oppressive stance.

(2000, p565)

They concluded that anti-oppressive practice needed to be re-evaluated to ensure that it properly reflects service users' views and aspirations. One way of ensuring this in the academic environment is, they suggest, to recognise that service user involvement should be across the curriculum and not just in those areas where the service users are deemed to be experts because of their experience of a particular service. Davis and Wainwright (2005) provide a useful reminder that even within the protected environs of academia a focus on social work's potential to change the life chances of the poorest sections of society should not be forgotten. This is an important reminder of how service user involvement needs to be mainstreamed rather than regarded as an add-on, even if a value add one, of social work education.

Within social work there has been a clear articulation of the importance of securing service user/carer involvement, (Anghel and Ramon, 2009). This is reflected in teaching (Waterson and Morris, 2005), assessment and peer review (Humphreys, 2005, Skoura-Kirk, et al. 2013), 'face to face' interactions between service users/carers and students and the use of video and other tools (Waterson and Morris, 2005). As Irvine, Molyneux and Gillman, (2015) argue the students they 
looked at had a, 'strong perception that their practice was improved by the input they had been given from service users and carers' (p.148).

\section{Different models of involvement}

Webber and Robinson (2012) have rightly stressed that service user/ carer involvement in social work education should be 'meaningful'. They suggest that models of involvement can be characterised in four ways: as a process of consultation; as a partnership in which the service user/carer contribution is 'equal to other contributors' (p.1268); as being political and contributing to wider political change or through a model of 'user control'. They suggest that more empowerment focused programmes will gravitate towards the latter models while those that see service user/carer involvement as bringing added value to the educational experience will be characterised by an emphasis on consultation and partnership. Robinson and Webber (2012) were not able to evaluate which of these models was the most effective although they suggest that the use of Arnstein's model of citizen participation can over-simplify complex considerations of how 'meaningful involvement is/can be (Arnstein, 1969). One example of an attempt to use Arnsteins model as an evaluative tool is that provided by Allain et al,(2006). Their conclusion was that they entered the process of involvement at the lowest phase (one of manipulation), that they succeeded in moving up Arnstein's ladder to rung five (placation) but that they had not reached a level which could really be regarded as partnership, delegation or control. This raises important questions about the efficacy of service user/carer involvement which, in this paper, and in much of the literature, is posited as a good. A review of the evidence supporting this position is beyond the scope of this paper which focusses on attempting to develop a new theoretical framework for exploring this involvement. However such a review is the focus of a separate piece of work which will evaluate not only the effectiveness, but also the sustainability, within education and professional practice, of such work.

Clearly the ability to exercise control within a modern, often neo-liberal, university environment would be a difficult task. It does raise important issues however as to how the power differentials between people using social work services and universities can be articulated. These issues will form an important element of the discussion of how we can conceptualise the involvement of service user/carers in our work which will be developed below. Before that however an outline of the ways in which service user/care involvement has been developed at the University of Portsmouth will be provided to contextualise this debate.

The University of Portsmouth - Social Work Inclusion Group (SWIG): an example 
SWIG has been established in slightly different forms since June 2004 with support of money provided by the General Social Care Council to secure the involvement of service users in the delivery of social work education. Since its formation the group has been involved in the following activities:

Table 1: service user/carer involvement at the University of Portsmouth

\begin{tabular}{|c|c|}
\hline - interviewing and admissions procedures; & $\begin{array}{l}\text { teaching - the group was one of the } \\
\text { pilot groups chosen by Skills for } \\
\text { Care to deliver a training } \\
\text { programme to train service users } \\
\text { to teach on the Portsmouth social } \\
\text { work degree programme }\end{array}$ \\
\hline - redesigning the curricula; & $\begin{array}{l}\text { - } \text { assessing students 'Readiness for } \\
\text { Practice' at the end of the first year } \\
\text { (UG) or first semester (PG) }\end{array}$ \\
\hline $\begin{array}{l}\text { - producing a video, 'What I want from a } \\
\text { social worker' and a series of DVDs for } \\
\text { Palgrave's Social Work Toolkit; }\end{array}$ & - assessing student presentations; \\
\hline $\begin{array}{l}\text { - developing a range of drama and cultural } \\
\text { activities for use in social work training, } \\
\text { particularly around a) a CREATE day in } \\
\text { which people who use social work } \\
\text { services work with groups of social work } \\
\text { and creative arts students to produce a } \\
\text { creative artefact such as a photographic } \\
\text { exhibition, a piece of drama or film, a } \\
\text { poem etc. b) the Black and White/ } \\
\text { Perspectives project which involves } \\
\text { service users/cares co-producing a series } \\
\text { of photographic representations of the } \\
\text { service user/carer experience(for more } \\
\text { detail see Hatton, 2013, Ch. 4, see also } \\
\text { Pauvels, 2010) c) Debate Days for first } \\
\text { year students }\end{array}$ & $\begin{array}{l}\text { - assessing presentations by } \\
\text { applicants seeking academic } \\
\text { positions; }\end{array}$ \\
\hline $\begin{array}{l}\text { - small-scale research around homelessness, } \\
\text { working with ex street homeless people } \\
\text { and homelessness organisations as co- } \\
\text { researchers. }\end{array}$ & $\begin{array}{l}\text { - auditing work placements - the } \\
\text { group is currently designing an } \\
\text { audit tool to assess whether } \\
\text { placement agencies meet } \\
\text { students' learning needs; }\end{array}$ \\
\hline
\end{tabular}


(see www.swig.uk.net).

SWIG's experience illustrates the point made by Foucault about the pace at which we seek to secure meaningful change. He spoke of the need to proceed a little at a time. Yet many agencies, in the desire to be seen to be ticking all the right boxes, treat service user involvement as if it is an immediate imperative and the service user should sublimate their own needs to achieve it. In 2005, SUIG, (the Service User Inclusion Group, the precursor of SWIG), along with a number of other service user organisations, were commissioned by the Training Organisation for the Personal Social Services (TOPSS; now Skills for Care) to undertake training of service users to enable them to teach on the new social work degree. SUIG was encouraged to pilot a training programme in two cities in the South. When the agreed start date for the training arrived, TOPSS had not produced the relevant training material and the group needed to develop their own. TOPSS appeared to think that training could be easily rescheduled. They appeared to have had no understanding that service users were themselves extremely busy people, with their own schedules, and they also appeared to be unaware that SUIG members had their own expectations and aspirations, which they had invested in the programme (SUIG, 2005). The hard copies of the training material arrived only after the project had finished. This illustrates the point made by Wilson and Beresford (2000) when they spoke of how there was a real danger that service users' views and aspirations could be appropriated by larger, more powerful, professional or sectoral organisations (see also Allain et al, 2006).

\section{Conceptualising the involvement of people using services in social work education}

The theoretical underpinning for such an approach has frequently been under-conceptualised. Generally involvement has been seen as good and part of a broader inclusion agenda which seeks to engage with the empowerment of people using social work services (users and carers). It has focused on the importance of power relationships (Tew, 2006, Dominelli, 2010 ), the need for service user 'voice' (Beresford, 2013) and has been critical of managerialist and procedural approaches to engagement with people using social work services (Jordan, 2011) particularly in the age of austerity (Jordan and Drakeford, 2012) 
However even these areas, although often highlighted, could be further developed. Power discourses have drawn on a range of writers from sociology, political philosophy and from within the social work and community work literature. Lukes (1975) suggested that power needs to be understood in three ways: as the capacity to act (A having the power to make $B$ do something against their wishes); as the management of dissent by the prevention of issues being placed on the public agenda; and by the lack of recognition on the part of powerless groups that their interests are being threatened (Lukes, 1975, 2004 Hindess, 1996).

Foucault (1991) reminds us that power operates in a complex way and that we need to interrogate our understanding of power at macro and micro levels. He argues that:

[T] he problems which I try to address ... which involve daily life, cannot be easily resolved. It takes many years, decades of work carried out at grass roots level with the people directly involved, and the right to speech and political imagination must be returned to them (my emphasis) ... the complexity of the problem will be able to appear in its connection with people's lives ... the object is to proceed a little at a time, to introduce modifications that are capable of, if not finding a solution, then at least changing the givens of a problem (pp 158-159).

While Foucault was addressing issues of political power in the broad sense, his comments can just as easily be seen as a prime legitimation for our concern with involving people who use social work services. Work with service users and carers is specifically about releasing people's political imagination so that they can envision an alternative experience, a different way of experiencing and delivering welfare and social work services. It is also about focusing on the particular daily experience of those people most directly involved in delivering social work services. It is concerned with changing the way issues are framed so that service users are not seen as 'problems' or 'clients' but rather as active partners in changing the services they directly experience. As Castells argues, we need to

live with the tension, and the contradiction, between what we find and what we would like to happen. I consider social action and political projects to be essential in the betterment of a society that clearly needs change and hope.

(2000, p389, emphasis added) 
This suggest that engaging and creating partnerships with people who use social work services has a change dimension, it is essentially political, which means that when examining service user/carer involvement we need to ask, (Webber and Robinson, 2012) whether the involvement we are discussing is real or tokenistic. This is a key focus of this paper where it is argued that to achieve this we need to have a multi-dimensional concept of power which incorporates a range of variables as illustrated in figure 1.

Figure 1

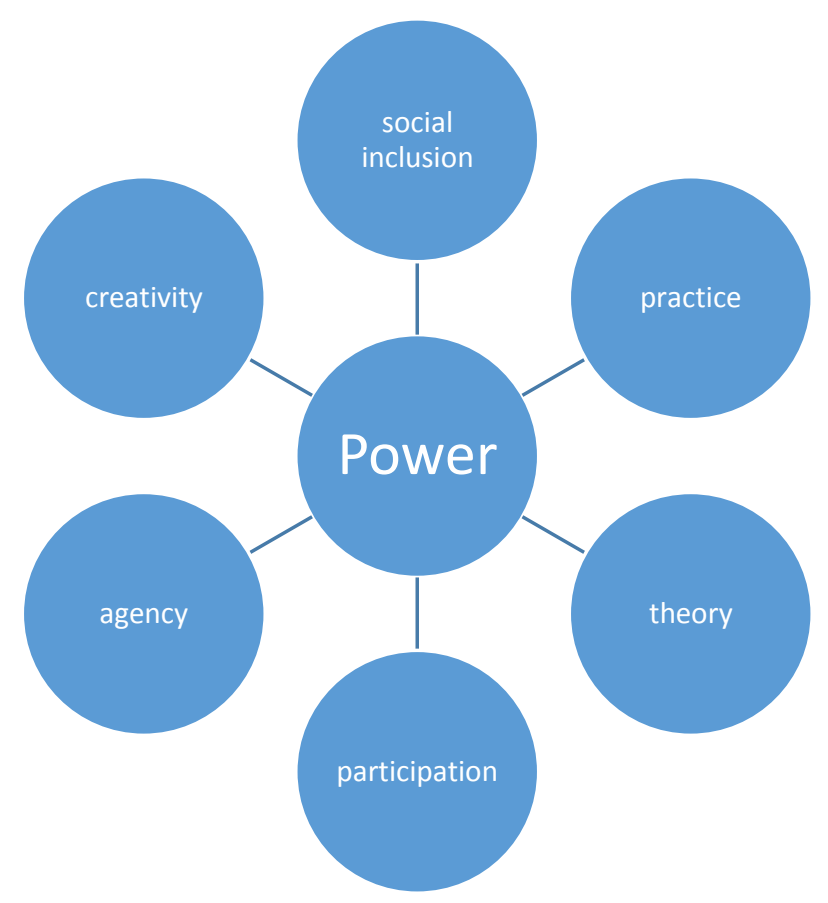

This concept of power includes inclusion/participation, the link between theory and practice, the actualisation of personal and political power through creativity and artistic action and an underpinning commitment to the recognition of agency as the determining factor in people realising their potential.

Service users/ carers attribute great importance to their having a significant role in training and educating social workers. Their concern is not just to highlight issues but to contribute to the development and improvement of services. Such an involvement is essential if services are to be able to meet the demands placed on them in the new welfare mix. 
Values

This raises a question about how we can create sets of values which challenge existing power relationships, particularly in view of the fact that these relationships are not always as obvious or visible as might be expected. Gramsci (1971) maintained that ruling classes dominate through a mixture of force and consent, where the consent is gained through assuming the political, moral and intellectual leadership in society. He argued that civil society (political parties, churches, cultural, charitable and voluntary groups) are central in maintaining hegemony. Civil society is the place where democratic struggles can be linked together. The ruling class maintains control by making their rule and the legitimacy of state rule appear like 'common sense'. It is then the role of external agents, such as intellectuals, union organisers and community leaders, to challenge this common sense. He believes that an oppressed group needs its own organic intellectuals (those that emerge from within their own ranks) to challenge these dominant ideas. He argues that

'everyone' is a philosopher ... it is not a question of introducing from scratch a scientific form of thought into everyone's individual life, but of renovating and making 'critical' an already existing activity.

(Gramsci, 1971: 330-1, cited in Allman, 2001, p114)

There is a danger that without an analysis of the way in which ideas are mediated we reproduce an analysis which suggests that service users are passive in the face of the institutional power of large social work or professional agencies. Yet from this reading of Gramsci when can see service users/carers struggling to have their voices heard are themselves 'organic intellectuals'.

How can we acknowledge the capacity of service users to take action to gain power rather than have power handed to them (which must in any case be an unlikely scenario)? We can do this by seeing service users as people with the capacity to bring about change not only in their own, individual circumstances, but in the broader institutions and structures against which they struggle. As such empowerment becomes central to the service user/care experience. In this sense we can see empowerment as essentially a strategy to bring about personal and political change (Hatton, 2015) 


\section{Promoting meaningful change}

To make involvement and participation real, we need to look not just at how power can be exercised but also at how it can be resisted. How can we develop strategies to promote meaningful change? Giddens' analysis of agency and structure can provide some pointers as to how this may occur. He refers to power as 'the transformative capacity of human action' (Cassell, 1993, p109). This, Giddens (1979) suggests, following Marx, is the key element in the notion of praxis. The creation of a radical practice, based on notions of overcoming oppression, tackling discrimination/oppression and the creation of new cooperative social relationships, is at the heart of any theory of social action. Similar ideas can also be seen in Freire's idea of 'conscientisation', the notion that when the person becomes aware of the way their oppression is determined they develop the capacity to take action to change their situation (Gramsci, 1971; Freire, 1972; Burr, 1995; Mayo, 1999).

Foucault (1980) points to the way in which power is:

localised, dispersed, heteromorphous and accompanied by numerous phenomena, of inertia, displacement and resistance, so that, one should not assume a massive and primal condition of domination, a binary structure with "dominators" on the one side and "dominated" on the other (p142).

Power should be viewed as a dynamic concept in which individuals 'are always in the position of simultaneously undergoing and exercising ... power [they] are the vehicles of power, not its application' (p98). Foucault suggests that 'the mechanisms of power [need to be analysed] on the basis of daily struggles at grass roots level, among those whose fight was located in the fine meshes of the web of power' (p116). This is the agency that we, as social workers, academics and users/carers, are looking for, the sense that service users can resist and reframe their experience in a way that can change the way services are delivered. However, it is necessary to avoid an outcome in which the organisation benefits more than the service user. As Jordan noted, outcomes can be seen in significantly different ways:

the agencies' goal is to get target groups to bear as much of the costs of social care as possible, without sacrifice of professional power or significant material resources; the groups' to gain relevant resources and influence policy. 
(1996, p185)

There is a need to identify why people act or fail to act to redress any disadvantage they experience. Underpinning the need for a focus on participation/inclusion is a commitment to recognise the agency of service users. Giddens' concept of agency, is characterised by 'human action' or what Fook has characterised as a 'sense of responsibility, of agency, an appreciation of how each player can act upon it to influence a situation' $(2002$, p200). Central to this, Fook suggests, is the development of a consciousness, which can imagine another different way of doing things, a point similar to that attributed to Foucault earlier in this paper (Foucault, 1981). Hatton, (2015) has suggested that this would enable, 'the creation of a radical practice based on notions of overcoming oppression, tackling discrimination/oppression and the creation of new cooperative social relationships, (which are) at the heart of any theory of social action' (p. 113).

\section{Service user involvement and social pedagogy}

The importance of such an approach is evidenced by Akcelrud Durão (2006) who argues that it is essential that for social action to be effective arguments for change need to emerge from excluded communities or in our case from service users/carers themselves (p.93). One way in which this can be seen is through the prism of the European concept of social pedagogy (Hatton, 2013) which is defined by Hamalainen (2003) as 'the basic idea...(of social pedagogy) is to promote people's social functioning, inclusion, participation, social identity and social competence as members of society (p.76). This commitment to social action is recognised as a central tenet of social pedagogy by a number of writers including Hämäläinen (2003). This is also reflected in Vygotsky's idea of the 'creative imagination' which occurs 'whenever a person imagines, combines, alters and creates something new' $(2004, \mathrm{p} 11)$. This will involve setting agendas for change, not just responding to the agenda of those with power (Jordan and Drakeford, 2012) and developing new participatory organisations and practices which signify real and lasting change. This would clearly illustrate Foucault's point about individuals simultaneously undergoing and exercising power and would help us understand the way power operates (Foucault, 1980).

Lorenz (1994) argues that social pedagogy 'signifies a concept which pays attention to the formation of society as a whole' (p. 92) and suggests that one alternative is to take on 'the critical conscience of pedagogy, the thorn in the flesh of the official agenda, an emancipatory programme for selfdirected learning processes inside and outside the education system geared towards the transformation of society' (p. 93). 
Central to a pedagogues activity is the use of head, heart and hands. The former enables the pedagogue to develop an understanding of the reasons for their intervention, the heart indicated the regard for and empathy with the person or group with whom the pedagogue is intervening and the hands indicate the range of practical and creativity which the pedagogue uses in any intervention (Boddy and Statham, 2009).

Hamalainen, argues that social pedagogy:

aims to alleviate social exclusion. It deals with the processes of human growth that tie people to the systems, institutions and communities that are important to their well being and life management.

(Hamalainen, 2003:.76)

\section{'The Common Third'}

Similar to social work, social pedagogy has a varied theoretical and practical tradition. An example is the Danish tradition of social pedagogy which draws on a range of sources from Freire to Kierkegaard (Hatton, 2001). Central to this approach is the 'Common Third' which Aabro describes as a descriptive project or ambition within the pedagogical tradition of 'relations in social work in which there is a 'deliberate focus on the object as something outside the subject. The object being a 'common thing' which both parts in the relation' can connect with' (see Hatton 2006: 2008). Aabro describes the work of Husen who sees the key element of social pedagogy as being:

To be sharing something, to have something in common, implies in principle to be equal, to be two (or more) individuals on equal terms, with equal rights and dignity (subject - subject relation). In a community you don't use or exploit the other (subject- object relation).

(Husen, 1996: 231, translated by Aabro, 2004 in Hatton, 2015: 135 -6)

At the core of this relationship are notions of equality and respect and the eradication of unequal power relations. Cacinovic Vogrincic (2005) argues that the social pedagogue or social worker needs to develop a new language and concepts but makes, 'the co-creation of solutions together with the client possible' (p.336). He suggests that such an approach is based on an agreement to work, common understandings, a focus on participation, a focus on strengths rather than weaknesses and finally what he calls co-presence, which he says is about, 'confrontations, understanding, agreements... (as)... sources of new experience and possible changes' (p.338). He suggests that the key to these elements is the transfer of professional knowledge into professional action 
As Aabro suggests it is 'through a common or joint activity (that) the users and the social workers enter a subject -subject relation..(in which)...the professional is meant to "forget himself" and the things around him - and devote entirely to the process and activity...the pedagogical challenge is to be able to realise activities which don't reflect the interests and needs of only one part, but instead seek to establish a common and productive activity.' (Aabro's emphasis in Hatton, 2006). One respondent to the review of social pedagogy in Essex undertaken by Eichsteller and Holthoff (2012) commented positively on their experience of using the 'Common Third', saying:

I now give great emphasis to using the 'Common $3^{\text {rd }}$ approach' to building relationships with the young people. Seeking out opportunities via a seemingly endless scope of activities will allow for valuable bonding between two individuals or groups...I decided to utilise my time and get out of my comfort zone... I made the most of building positive relationships with all the young people. I remarketed myself as accessible and traded admin for activities.

\section{From understanding to action}

Diesterweg, a German educationalist, a contemporary of Kant, Froebel and Pestalozzi argued that it was important to emphasise the democratic nature of education, with a particular focus on the social context within which education took place. He argued that, 'all (educational) theory separated from practice' is ineffectual and inappropriate (Gunther, 1993:296) and regarded equality as the key to educational provision. He saw education as a means of improving people's situation and promoting self-development.

A more recent influence on Danish pedagogy has been the work of Friere (Hatton, 2001, 2015; Eriksson and Markistrom, 2003). Friere (1972) argues that a key way in which people without power are marginalised is through a process in which their behaviour becomes pathologised and their human nature is constructed in a distorted way through what he describes as processes of indoctrination, manipulation and 'dominated consciousness'. He argues that as a result people lack the consciousness or understanding to decode their situations. He argues therefore that we should encourage people to see the commonality of their situation, that this focus on the common interest can only be achieved through a process which he describes as conscientanzo. This is a process through which people not only become aware but act on that awareness.

Noting the influence of Freire, Eriksson and Markstrom (2003) suggest that the key contribution of Freire to social pedagogy is his emphasis on social mobilisation and emancipation. In this context they see social pedagogy as a means of initiating a process through which people mobilise their own resources. Marynowicz-Hetka (2007) suggests that social pedagogy can orientate practitioners 
towards the field of social action. She suggests that, an important part of the social pedagogic approach, are what she characterises as:

reflection on the possibilities of learning... to act in/through and for communities...analysis of other solutions outside the traditional areas of social pedagogy, and their application to optimise and transform social practice' (2009: 4).

\section{The role of creativity}

An important element of this approach is a focus on creativity and art. Vygotsky's focus on creativity and imagination suggests a way forward. Our creative actions are, he argues, based on our use of imagination which is:

The basis of all creative activity, ...an important component of all aspects of cultural life, enabling artistic, scientific, and technical creation alike....whenever a person imagines, combines, alters and creates something new, (they are engaging their creative imagination) (p.11)

Vygotsky sees this creative process as being dependent on both current environmental context and previous historical development. Creative developments then can be linked to processes of structural and class oppression. To free the creative imagination is to challenge the organisation of the society in which we live and to improve the life chances of the people we work with. Finally he reminds us of the 'agonies of creation'. As he says, 'creation is difficult, the drive to create does not always coincide with the capacity to create, and this is the origin of the agonizing feeling of suffering caused by the fact that the word does not capture the thought' (p.39). Despite this he concludes by advocating the particular importance of cultivating creativity (p.87).

Hacking, Secker, Spandler, Kent and Schenton (2009) describe the way in which an arts project in the UK sought to engage with people with mental health needs. They found small but significant increases in social inclusion and indications that people were building stronger immediate networks and significant improvement in the overall empowerment of participants. They suggest that there were five processes which could be seen to be linked to the increased empowerment of the participants. These included:

- Getting motivated - they describe this as the participants developing inspiration and pride in their art work which in turn gave them a sense of purpose.

- Expressing self -through creating art the participants began to discover and accept themselves, this was particularly true of those participants with complex mental health issues, difficult past experiences and those who self-harmed. 
- Connecting with abilities, rebuilding identities and changing peoples' perceptions of themselves.

- Expanding horizons - they suggest that people began to see themselves as having an identity as an artist rather than of a mental health service user. They quote one participant who says; "It's not just something that someone with mental health problems has produced, its something that an artist has produced and it just so happens that they have got mental health problems as well". (FEANTSA, 2009: 12/13)

Youth Music, a UK charity focusing on transforming the lives of marginalised and disadvantaged young people in the UK see music as a means of enabling young people and allowing them to take control of their lives. Their work, 'explores the outcomes that can be achieved through music-making projects for looked after children, and the barriers and facilitators to the effective delivery of these projects (Dillon, 2009:4). They maintain that, 'music-making can contribute to the development of a wide range of social and personal development outcomes for looked after children'

Gray and Webb (2008) warn however of the danger of sentimentalising the use of creativity, intuition and a focus on the aesthetic side of social work in that it can also be:

indicative of a reactionary sentiment that partly relates to a sense of mourning, or a loss progressively engendered by the deskilling of the task, the degradation of work, the reduction of professional autonomy, the break-up of professional identities and the consumerist marketisation of clients as 'service users' ( $p, 184)$

Gray and Webb (2008) argue instead for the idea of 'art as struggle' or of 'an art in the service of a politics of liberation' (p.184) as being based on a sense of mutuality, partnership and equality. Lymbery (2003) suggest a solution may be found by recognising, but seeking to resolve, the contradiction between competence and creativity in social work. Lymbery (2003) suggests that in practices which involve assessment and/or evaluation skills the competence underpinning this work is insufficient and needs to be enhanced by ' the creativity that characterises best social work practice' (p.114). Indeed Fazzi (2015) has pointed to the way the focus on the professionalisation of social work and the increased focus on specialisation are likely to, 'reduce the creativity and innovation' in our work.

To summarise a creative approach can have relevance across the helping professions. Play, music, drama, awareness of the body can be employed in work with siblings, mental health users, people with physical and intellectual disabilities and in the care of older people. An understanding of the theory behind creative activity can promote, reflection and learning in a variety of contexts. 


\section{The CRISP model}

A model which suggests a way of linking these divergent thoughts together is the one which lies behind the service user/care involvement work in Portsmouth. The CRISP (Creativity, Inclusion, social pedagogy) model is an attempt to build a model of social theory and practice which makes explicit the need for creativity and inclusion to be part of the pedagogic/social work task (Hatton, 2013). The approach advocated suggests that the missing link between the creativity, which it is suggested is essential to good, empowering practice and social pedagogy is the notion of inclusion. Creativity suggests a way of realising the potential of people working in and making use of welfare services. Social pedagogy is predicated on equal partnerships between people working in and using welfare services. Both are central to the idea of inclusion. Inclusion provides the philosophical, practical and professional rationale for joining together creativity and social pedagogy and achieving a 'politics of liberation' as suggested by Gray and Webb (2008).

It is now widely accepted that a focus on inclusion is central to good social professional practice (Hatton, 2015; Beresford and Hoban, 2005). Those involved with radical social and community work will appreciate the difficulty of achieving real inclusion rather than the often tokenistic attempts at inclusion which agencies seek to perpetuate (Arnstein, 1969: Hatton, 2015; Stepney and Popple, 2008; Ferguson and Woodward, 2009). However, one of the reasons for adopting such an approach is that it can produce a sense of localism which can connect us to the people with whom we work. Such an approach should be at the centre of any involvement strategy.

Heikkila and Junkunen (2003) suggest that a number of key principles should underpin this commitment to inclusion. These include:

- Involvement as a right and responsibility - there should be a democratic right for service users to be involved...

- All service users should have access to services of sufficient quantity and quality...

- All services should have a culture of service user involvement.

- Users should be seen as recipients and actors - they should play a full role in decisions and debates around social care.

- Full accounts should be taken of users networks as a way of maximising user involvement.

\section{Inclusion and choice}

However, it is important to recognise that the encouragement of involvement or inclusion is not the same as the way choice is presented in current prevailing social policy discourses. Jordan points to the potentially contradictory ways in which the question of choice is framed. He argues that an 
emphasis on choice and the user as consumer typifies the way the welfare state is developing, suggesting that 'the public infrastructure is redesigned so as to promote choice, giving citizens information (for instance in the form of league tables) about the performance of hospitals, school and care homes, so that they can switch to the best amenities (Jordan, 2006:142). Yet the reality is that within this scenario those without the material resources to make these choices real, lose out in a marketised form of welfare.

Inclusion and participation should therefore not be confused with a choice agenda which as currently expressed in the discourses of the current government can be seen as a neo-liberal attempt to mask the inequalities in existing provision and ensnare people into believing that they exercise control over the welfare services and welfare agencies with which they are involved.

A holistic view of our social interventions is reflected in some of the educational programmes offered at the University of Portsmouth. Social pedagogy and creativity are integrated into the social work curriculum at the University. Pete Shepherd (2012), a senior lecturer on the social work programme, says:

In the teaching of a creativity and empowerment unit the author and the students have worked alongside artists, poets and filmmakers who are engaged in changing perceptions and mainstreaming perspectives that have previously occupied the position of being 'outside' most institutions. (We seek to) critically evaluate how such a curriculum has been developed with the involvement of service users and been delivered to student groups over the last two years. We use creative artefacts to assess student's knowledge and their ability to embrace the principles of participation in their consultative work with service users and carers. (Shepherd, 2012 quoted in Hatton, 2013:38)

\section{Conclusion}

It is now generally accepted by the institutions of the state (Government departments and the HCPC), Higher Education Institutions, academics, students and users of social work services that the involvement of service users/carers in social work education is a good thing. This paper reflects this view but questions whether we need a more rigorous theoretical underpinning to this work. Clearly there is evidence of a recognition of power relationships, of the need for inclusion and for an understanding of the importance of the service user/carer 'voice'. This paper seeks to build on these insights to suggest a conception of involvement which develops these concerns and provides a deeper conception of power, the importance of involvement, inclusion and participation and the need for us to embrace creativity as a way of enhancing such involvement. 
The paper draws on European debates around creativity, models of social pedagogy and the experience of delivering a creative agenda at the University of Portsmouth. It is suggested that we need to fuse together a multi-dimensional analysis of power, (with a particular focus on the idea that we co-produce learning activities and experiences), a recognition of the degree of agency exercised by people using social work services and a commitment to using our own and our collective, creative (and political) imaginations to work in new ways. This means moving beyond traditional measures of involvement such as teaching assessment and interviewing to a wider concept of us all as drivers of the learning experience and creators of the curricula.

To this extent this paper should be seen as an exploratory discussion which raises important issues about the centrality of service user/carer involvement in social work education. As such it will provide the framework for a deeper evaluative study as to the efficacy and sustainability of such approaches.

\section{References}

Akcelrud Durao, F (2006)Towards a model of Inclusive Exclusion: Marginal Subjectivation in Rio de Janerio, A Contra corriente, A Journal of Social History and Literature in Latin America, 3,2, 88 - 106

Allman, P. (2001) Revolutionary Social Transformation: Democratic Hopes, Political Possibilities and Critical Education. Westport, CT: Bergin and Garvey.

Anghel \& Ramon, S (2009) Service users and carers involvement in social work education: lessons froman English case study, European Journal of Social Work 12;2, 185 - 199

Allain, L Cosis Brown, H Danso, C Dilion, J Finegan, P Gadhoke, S Shamash, M \& Whitaker, F (2006) User and Carer involvement in Social Work education - A University case Study: Manipulation or Citizen Control, Social Work Education 25:4, 403 - 413

Arnstein, S. (1969) 'A ladder of citizen participation', Journal of the American Institute of Planners, 35 (4), 214-24.

Bennett, F. and Roberts, M. (2004) From Input to Influence: Participatory Approaches to Research and Inquiry into Poverty. York: Joseph Rowntree Foundation

Beresford, P. (2013) 'Service user issues: Rights, needs and responsibilities', in B. Littlechild and R. Smith (eds), A Handbook for Inter-Professional Practice in the Human Services: Learning to Work Together. Harlow: Pearson.

Beresford, P. and Hoban, M. (2005) Participation in Anti-poverty and Regeneration Work and Research: Overcoming Barriers and Creating Opportunities. York: Joseph Rowntree Foundation.

Boddy, J and Statham, J (2009) European Perspectives on Social Work: Models of Education and Professional Roles, London, Thomas Coram Research Unit, Institute of Education 
Cacinovic Vogrincic, G (2005) Teaching concepts of Help in Social Work: The Working Relationship, European Journal of Social Work, 8:3, 335 - 41

Cassell, P (ed) (1993) The Giddens Reader, Basingstoke, Macmillan

Castells, M (2000) End of the Millenium, London, Wiley

Children's Rights Alliance and National Youth Council of Ireland (2002) Hearing Young Voices. Dublin: The Open Your Eyes to Child Poverty Initiative. Available from www.youth.ie/sites/youth.ie/files/Hearing YoungVoices-Full.pdf (accessed 16/2/15).

Davis, A and Wainwright, L (2005) Combatting Poverty and Social Exclusion: Implications for social work education, Social Work Education, 24 (3): 259 - 73

Department of Health (2001) Valuing People: A New Strategy for Learning Disability for the 21st Century. London: HMSO.

Department of Health (2009) Valuing People Now: A New Three Year Strategy for People with Learning Disabilities, London, Stationary Office

Department of Health (2010a) A Vision for Adult Social Care: Capable Communities and Active Citizens. London: Department of Health.

Department of Health (2010b) Personalisation through Person-Centred Planning. London: Department of Health.

Dillon, M (2009) available at www.youthmusic.org.uk

Dominelli, L (2010) Social Work in a Globalising World, Cambridge, Polity

Eischteller, G and Holthoff, S (2012) The Art of Being a Social Pedagogue in Practice:

Examples of Cultural Change in Children's Homes in Essex, Manchester, Thempra Social Pedagogy

Eriksson, L and Markstrom, A.M. (2003) Interpreting the Concept of Social Pedagogy Gustavsson, A Hermansson, HE and Hamalained, J (eds) Perspectives and Theory in Social Pedagogy, Gotenburg, Bokforlaget, DaidLOS

Fazzi, L (2016) Are we Educating Creative Professionals? The Results of Some Experiments on the Education of Social Work Students in Italy, Social Work Education, 35:1, 89 -99

FEANTSA (2009) Homeless in Europe - Homelessness and the Arts: Creativity, empowerment and social change, Spring, The magazine of the European Federation of National Working with the Homeless, AISBL, Spring. Available from www.feantsa.org/spip. php?article1027\&lang=en (accessed 16/2/15).

Ferguson, I and Woodward, R (2009) Radical Social Work in Practice: Making a Difference, Bristol, Policy Press

Fook, J (2002) Social Work: Critical Theory and Practice, London, SAGE 
Foucault, M. (1980) Power/knowledge: Selected Interviews and Other Writings. Brighton: Harvester Wheatsheaf.

Foucault, M (1991) Remarks on Marx, New York, Semiotext Books

Freeman, R Chamberlayne, P Cooper, F and Swanson, M (1996) Conclusion: A new culture of welfare in P. Chamerlayne, A, Cooper, R Freeman and M Rustin (eds) Welfare and Culture in Europe: Towards a New Paradigm in Social Policy, London, Jessica Kingsley

Freire, P (1972) Pedagogy of the Oppressed, London, Penguin

Giddens, A (1979) Central Problems in Social Theory: Action, Structure and Contradiction in Social Analysis, Basingstoke, Macmillan Education

Goodley, D (2011) Disability Studies: An Interdisciplinary Introduction, London, SAGE

Gramsci, A (1971) Selections from the Prison Notebooks of Antonio Gramsci: Ed. and Transl. by Quintin Hoare and Geoffrey Nowell Smith. London, International Publishers

Gray, M and Webb, S ((2008) Social Work as art revisited, International Journal of Social Welfare, 17, $182-193$

Gunther, KH (1993) Freidrich Adolph Diesterweg (1790 - 1866) downloaded from www..ibe.unesco.org/fileadmin...upload/archive/publication/ThinkersPDF/diestetere.pdf on $3 / 12 / 2012$

Hacking,S Secker, J Spandler, H, Kent L and Shenton, J (2009) The Empowerment of People with Mental Health Needs and Other Social Exclusion Impacts: Using Arts Participation: Evidence from the UCLAN/Anglia Research Project, Homelessness in Europe, Spring available from www.feantsa.org/spip. php?article1027\&lang=en (accessed 16/2/15).

Hamalainen, J. (2003) 'The concept of social pedagogy in the field of social work', Journal of Social Work, 3 (1): 70-80.

Hayden, C., Goddard, J. Gorin, S. and Van Der Spek, N. (1999) State Child Care: Looking After Children? London: Jessica Kingsley.

Hatton, K. (2001) 'Translating values: Making sense of different value bases - reflections from Denmark and the UK', International Journal of Social Research Methodology, 4 (4): 265-78.

Hatton, K. (2006) 'Europe and the undergraduate programme', in K. Lyons and S. Lawrence (eds), Social Work in Europe: Educating for Change. Birmingham: BASW/Venture Press.

Hatton, K (2013) Social Pedagogy in the UK: Theory and Practice, Lyme Regis, Russell House Publishing

Hatton, K (2015) New directions in social work practice, (2nd ed) London, Learning matters/SAGE 
Heikilla, M and Junkunen, (2003) Obstacles to an increased user involvement in social services in Munday, B (ed) User Involvement in Personal Social Services, University of Kent, with assistance of the Group of Specialists on User Involvement in Social Services (CS-US), Strasbourg, Council of Europe

Hindess, B (1996) Discourses of Power: From Hobbes to Foucault, Oxford, Blackwell

Homeless Link Get Creative: Arts for All available at http://www.homeless.org.uk/ourwork/national-projects/get- creative-arts-for-all downloaded 30/07/15

Humphreys, C (2005) Service |User Involvement in Social Work Education: A Case Example, Social Work Education 24:7 797-803

International Federation of Social Workers (IFSW) (2014) Global Definition of Social Work, Berne, IFSW available from ifsw.org/get-involved/global-definition-of-social-work (accesses $30 / 07 / 15)$

Irvine, J Molyneux, J \& Giliman, M (2015) Providing a Link with the real world: Learning from the student experience of Service User and Carer Involvement in Social Work Education, Social Work Education 34:2, 138 - 150

International Federation of Social Workers (2014)

Jakes, S. and Cassidy, L. (n.d.) Evaluating the National Outcomes: Programme Outcomes For Communities, Citizen Development. Available from http://ag.arizona.edu/sfcs/cyfernet/nowg/cd_indicators.html (accessed 16/2/15).

Jarldon, M Beddoe, L Fraser, H \& Michell, D (2015) Planting a Seed: encouraging service users towards educational goals, Social Work Education, 34:8, 921 - 935

Jordan, B (2006) Social Policy for the Twenty-first Century, Cambridge, Polity Press

Jordan, B and Drakeford, M (2012) Social Work and Social Policy under Austerity, Basingstoke, Palgrave, Macmillan

Lathlean, J Burgess, A Coldham, T Gibson, C Herbert, L, Levett-Jones, T Simons, L Tee, S (2006) Experiences of service user and carer participation in health care education, Nurse Education Today, 26, $732-737$

Local Authority Circular/Department of Health (2008), London, Department of Health Lorenz, W (1994) Social Work in a Changing Europe, London, Routledge

Lukes, S (1975) Power: A Radical View, Basingstoke, Macmillan

Lukes, S (1975) Power: A Radical View $2^{\text {nd }}$ ed, Basingstoke, Palgrave, Macmillan

Lymbery, M. (2003) 'Negotiating the contradictions between competence and creativity in social work education', Journal of Social Work, 3 (1): 99-117.

Marynowicz-Hetka, E (2007) Towards the Transversalism of social pedagogy, Social Work and Society, International Online Journal 5, 3 
McLaughlin, H (2009) What's in a Name: 'Client', Patient', 'Customer', 'Expert by Experience', 'Service User' - What's Next, British Journal of Social Work (2009) 39, 1101 1117

Miles, S. (2007) 'Different journeys at different speeds: Young people, risk and the challenge of creative learning', Journal of Youth Studies, 10 (3): 271-84.

Molyneux, J \& Irvine, J (2004) Service User and carer involvement in social work training; a long and winding road, Social Work Education, 23:3, 293 - 308

Pauvels, L (2010) Visual Sociology reframed: An analytical synthesis and discussion of Visual Methods in social and cultural research, Sociological Methods and Research 38 (4) $545-581$

Payne, M. (2014) Modern Social Work Theory, 4th edn. Basingstoke: Palgrave Macmillan.

Quetzal Tritter, J McCallum, A (2006) The snakes and ladders of user involvement: Moving beyond Arnstein, Health Policy 76, 156- 168

Ramsden, S (2010) Practical Approaches to Co-production: building effective partnerships with people using services, families and citizens, prepared for the DoH, London, HMSO

Robinson, K and Webber, M (2012) Models and Effectiveness of Service user involvement in Social Work Education: A Literature Review, British Journal of Social Work,1 - 20

Service User Inclusion Group (2005) 'Training Service Users to become actively involved in the new social work degree' - TOPSS England,

Shakespeare, T (2013) Disability Rights and Wrongs, London, Routledge

Skoura-Kirk, E Backhouse, B Bennison, G Cecil, B Keeler, J Talbot, D \& Watch, L (2013) Mark My Words! Service User and Carer Involvement in Social Work Academic Assessment, Social Work Education, 32:5, $560-575$

Social Care Institute for Excellence (2004) Position Paper No 3: Has service user participation made a difference to social care services, Bristol, Policy Press

Social Care Institute of Excellence (2004) Resource Guide No 2: Involving service users and carers in social work education, London, SCIE

Social Care Institute for Excellence (SCIE) (2013) Co-production in Social Care: What It Is and How to Do It, SCIE Guide 15. London: Social Care Institute for Excellence.

Stepney, P. and Popple, K. (2008) Social Work and the Community: A Critical Context for Practice. Basingstoke: Palgrave.

Tew, J. (2006) 'Understanding power and powerlessness: Towards a framework for emancipatory practice in social work', Journal of Social Work, 6 (1): 33-51.

Townend, M Tew, J Grant, A \& Repper, J (2008) Involvement of service users in education and training: A review of the literature and exploration of the implications for the education and training of psychological therapists, Journal of Mental Health, 17 (1): 65 - 78 
Vygotsky, L. (2004) 'Imagination and creativity in childhood', Journal of Russian and East European Psychology, 42 (1): 7-97.

Warren, J. (2007) Service User and Carer Participation in Social Work. Exeter: Learning Matters.

Waterson, J and Morris, K (2005) Training in Social Work: Exploring Issues of involving Users in Teaching on Social Work Degree Programmes, Social Work Education, Vol 24, No 6653 675

Webber, M and Robinson, K (2012) The Meaningful Involvement of Service Users and Carers in Advanced -Level Post-Qualifying Social Work Education: A Qualitative Study, British Journal of Social Work 42, 1256 - 1274

Wilson, A. and Beresford, P. (2000) "'Anti-oppressive practice": Emancipation or appropriation? British Journal of Social Work, 30: 553-73. 